\title{
Current Perspectives on Epigenetic Modifications by Dietary Chemopreventive and Herbal Phytochemicals
}

\author{
Yue Guo • Zheng-Yuan Su • Ah-Ng Tony Kong
}

Published online: 1 February 2015

(C) Springer International Publishing AG 2015

\begin{abstract}
Studies during the last two decades have revealed the involvement of epigenetic modifications in the development of human cancer. It is now recognized that the interplay of DNA methylation, posttranslational histone modification, and non-coding RNAs can interact with genetic defects to drive tumorigenesis. The early onset, reversibility, and dynamic nature of such epigenetic modifications enable them to be developed as promising cancer biomarkers and preventive/ therapeutic targets. In addition to the recent approval of several epigenetic therapies in the treatment of human cancer, emerging studies have indicated that dietary phytochemicals might exert cancer chemopreventive effects by targeting epigenetic mechanisms. In this review, we will present the current understanding of the epigenetic alterations in carcinogenesis and highlight the potential of targeting these mechanisms to treat/prevent cancer. The latest findings, published in the past 3 years regarding the effects of dietary phytochemicals in modulating epigenetic mechanisms, will also be discussed.
\end{abstract}

Keywords Epigenetic $\cdot$ Chemoprevention $\cdot$ Phytochemicals

\begin{tabular}{|c|c|}
\hline \multirow{2}{*}{\multicolumn{2}{|c|}{ Abbreviation }} \\
\hline & \\
\hline $\mathrm{APC}$ & Adenomatous polyposis coli \\
\hline AR & Androgen receptor \\
\hline \multicolumn{2}{|c|}{$\begin{array}{l}\text { This article is part of the Topical Collection on Epigenetics an } \\
\text { Phytochemicals }\end{array}$} \\
\hline $\begin{array}{l}\text { Y. Guo } \\
\text { Graduate Program } \\
\text { of Pharmacy, Rutg } \\
\text { Piscataway, NJ } 08\end{array}$ & $\begin{array}{l}\text { n Pharmaceutical Sciences, Ernest Mario School } \\
\text { rs, The State University of New Jersey, } \\
54 \text {, USA }\end{array}$ \\
\hline $\begin{array}{l}\text { Y. Guo } \cdot \text { Z.-Y. Su } \\
\text { Department of Pha } \\
\text { Rutgers, The State } \\
\text { Frelinghuysen Roa } \\
\text { e-mail: kongt@ph }\end{array}$ & $\begin{array}{l}\text { A.-N. T. Kong }(\triangle) \\
\text { maceutics, Ernest Mario School of Pharmacy, } \\
\text { University of New Jersey, Room 228, } 160 \\
\text { l, Piscataway, NJ 08854, USA } \\
\text { macy.rutgers.edu }\end{array}$ \\
\hline
\end{tabular}

\begin{tabular}{|c|c|}
\hline ATM & Ataxia telangiectasia mutated \\
\hline $\mathrm{BaP}$ & Benzo[a]pyrene \\
\hline $\mathrm{Bcl}-2$ & B cell lymphoma 2 \\
\hline $\mathrm{C} / \mathrm{EBP} \beta$ & CCAAT-enhancer-binding protein beta \\
\hline CCL2 & Chemokine ligand 2 \\
\hline $\mathrm{Cdc} 25 \mathrm{~A}$ & Cell division cycle 25 homolog A \\
\hline CREB2 & cAMP-response element-binding protein 2 \\
\hline CSF2 & Colony stimulating factor 2 \\
\hline CXCL1 & Chemokine ( $\mathrm{C}-\mathrm{X}-\mathrm{C}$ motif) ligand 1 \\
\hline CXCL10 & $\mathrm{C}-\mathrm{X}-\mathrm{C}$ motif chemokine 10 \\
\hline Cyclin D2 & G1/S-specific cyclin-D2 \\
\hline DADS & Diallyl disulfide \\
\hline DAPK & $\begin{array}{l}\text { Death-associated protein kinase } 1 \text { DIM, } \\
\text { diindolylmethane }\end{array}$ \\
\hline DNMT & DNA methyltransferase \\
\hline E-cadherin & Epithelial cadherin \\
\hline EGCG & (-)-Epigallocatechin-3-gallate \\
\hline EMT & Epithelial-to-mesenchymal transition \\
\hline $\mathrm{ER} \alpha$ & Estrogen receptor $\alpha$ \\
\hline EZH2 & Enhancer of zeste homolog 2 \\
\hline FOXO1 & Forkhead box protein $\mathrm{O} 1$ \\
\hline GCNT3 & Glycosyltransferase 3 \\
\hline GSTP1 & Pi-class glutathione S-transferase \\
\hline HATs & Histone acetyltransferases \\
\hline HDAC & Histone deacetylase \\
\hline HDMs & Histone demethylases \\
\hline $\mathrm{HIF}-1 \alpha$ & Hypoxia-induced factor \\
\hline hMLH1 & Human mutL homolog 1 \\
\hline HMTs & Histone methyltransferases \\
\hline $\mathrm{HO}-1$ & Heme oxygenase 1 \\
\hline IL-8 & Interleukin 8 \\
\hline MBDs & Methyl-binding proteins \\
\hline $\mathrm{MeCP} 2$ & Methyl CpG binding protein 2 \\
\hline MGMT & O6-alkylguanine DNA alkyltransferase \\
\hline miRNAs & MicroRNAs \\
\hline Neurog1 & Neurogenin-1 \\
\hline NQO1 & NAD $[\mathrm{P}] \mathrm{H}$ :quinine oxidoreductase-1 \\
\hline
\end{tabular}

ATM

$\mathrm{Bcl}-2$

$\mathrm{C} / \mathrm{EBP} \beta$

$\mathrm{Cdc} 25 \mathrm{~A}$

CREB2

CSF2

CXCL1

Cl10

lin D2

DNMT

E-cadherin

EMT

$\mathrm{ER} \alpha$

$\mathrm{ZH} 2$

GSTP1

HDMs

HIF-1 $\alpha$

hMLH

HMTs

IL-8

MBDs

$\mathrm{MeCP} 2$

MGMT

Neurog1
Ataxia telangiectasia mutated

B cell lymphoma 2

Chemokine ligand 2

Cell division cycle 25 homolog A

Colony stimulating factor 2

ligand 1

G1/S-specific cyclin-D2

Death-associated protein kinase 1 DIM, hane

Epithelial cadherin

Epithelial-to-mesenchymal transition

Estrogen receptor $\alpha$

Forkhead box protein $\mathrm{O} 1$

Glycosyltransferase 3

Histone acetyltransferases

Histone deacetylase

Human mutL homolog 1

Histone methyltransferases

Heme oxygenase 1

Interleukin 8

Methyl CpG binding protein 2

O6-alkylguanine DNA alkyltransferase

Neurogenin-1

$\mathrm{AD}[\mathrm{P}] \mathrm{H}$ :quinine oxidoreductase-1 


$\begin{array}{ll}\text { Nrf2 } & \text { Nuclear factor (erythroid-derived 2)-like 2 } \\ \text { PCAF } & \text { p300/CBP-associated factor } \\ \text { PEITC } & \text { Phenethyl isothiocyanate } \\ \text { PRB } & \text { Progesterone receptor B } \\ \text { PTEN } & \text { Phosphatase and tensin homolog, } \\ & \text { RASSF1A, Ras association domain- } \\ & \text { containing protein 1 } \\ \text { RUNX 3 } & \text { Runt-related transcription factor 3 } \\ \text { SAMD14 } & \text { Sterile } \alpha \text { motif domain containing 14 } \\ \text { SERPINB5 } & \text { Serpin peptidase inhibitor } \\ \text { SFN } & \text { Sulforaphane } \\ \text { SFRP1 } & \text { Secreted frizzled-related protein 1 } \\ \text { Smad4 } & \text { Mothers against decapentaplegic homolog } \\ & 4 \\ \text { SMPD3 } & \text { Sphingomyelin phosphodiesterase 3 } \\ \text { SPARC } & \text { Secreted protein acidic and rich in cysteine } \\ \text { TET } & \text { Ten-eleven translocation } \\ \text { TIMP-3 } & \text { Matrix metalloproteinase-3 } \\ \text { TMS1 } & \text { Target of methylation induced silencing-1 } \\ \text { TNFaip3 } & \text { Tumor necrosis factor, alpha-induced pro- } \\ & \text { tein 3 } \\ \text { TPA } & \text { 12-O-Tetradecanoylphorbol-13-acetate } \\ \text { UGT1A1 } & \text { UDP-Glucuronosyltransferase 1 family, } \\ & \text { polypeptide A1 } \\ \text { WIF-1 } & \text { Wnt inhibitory factor 1 } \\ & \end{array}$

\section{Introduction}

Cancer is a disease involving dynamic changes in the genome. The activation of oncogenes and the loss of function of tumor suppressor genes due to genetic mutations have long been considered the driving force of neoplasia [1]. However, the important contribution of epigenetic events to the malignant phenotype has been recognized with the help of significant advancements in the field of cancer epigenetics [2]. The definition of "epigenetic" has evolved over time from the impact of chromatin structure on embryonic development to its implication in a wide variety of biological processes [3]. Currently, the term "epigenetic" refers to the study of heritable alterations in gene expression without changes in the primary DNA sequence [4]. These heritable alterations are primarily established and maintained through cell differentiation and division, enabling the cells with the same genetic information to have distinct identities. The major epigenetic mechanisms for regulating these heritable gene alterations are the methylation of cytosine bases in DNA, covalent modifications of histones, and posttranscriptional gene regulation by microRNAs (miRNAs) [2]. The disruption of these epigenetic modifications is associated with abnormalities of various signaling pathways and can lead to the induction and maintenance of many disease states, including cancer [5].
It is now widely accepted that epigenetic abnormalities and genetic alterations in cancer cells may interact at all stages to initiate and promote cancer $[6,7 \bullet \cdot]$. In contrast to genetic mutations, epigenetic modifications are potentially reversible. For example, genes with repressed transcriptional activity by epigenetic silencing can be reactivated through epigenetic interventions because the genes themselves are still intact, whereas genetic mutations are permanent. This fact may explain why increasing attention and effort had been focused on the discovery and development of epigenetic-targeted therapeutics to treat cancer in recent years. To date, several smallmolecule epigenetic therapies targeting chromatin-modifying enzymes have been developed and approved for cancer treatment by the US Food and Drug Administration (FDA). These drugs include DNA methyltransferase (DNMT) inhibitors (azacitidine and decitabine) and histone deacetylase (HDAC) inhibitors (vorinostat and romidepsin) [8•]. A number of clinical trials are also underway with these agents and many other newly developed epigenetic agents in a variety of cancer types. Moreover, the synergistic effects between epigenetic drugs and conventional antitumor therapies are quite promising [9]. Other than these small-molecule agents, accumulating evidence suggests that the epigenetic landscape is largely influenced by dietary and environmental factors [10]. With their relatively low toxicity, feasible long exposure, and promising effects observed in vitro and in vivo [11, 12], dietary phytochemicals may become potential chemopreventive agents by targeting epigenetic modifications.

In this review, we will discuss the current understanding of the epigenetic mechanisms that occur during carcinogenesis and highlight their potential roles in cancer chemoprevention. Studies published in the past 3 years regarding the impact of dietary chemopreventive phytochemicals in modulating epigenetic alterations will also be reviewed and discussed.

\section{DNA Methylation}

DNA methylation, the addition of a methyl group by DNMTs to the cytosine bases located $5^{\prime}$ to a guanosine in a CpG dinucleotide, is perhaps the most extensively investigated epigenetic modification in mammals [13]. CpG dinucleotides are not evenly distributed across the entire genome but are clustered in short regions known as $\mathrm{CpG}$ islands that are $0.5-4 \mathrm{~kb}$ in length [13]. These $\mathrm{CpG}$ islands are known to be preferentially located in the proximal promoter end of approximately $60 \%$ of genes in the genome and generally remain unmethylated in normal cells [14, 15], allowing access to transcription factors and chromatin-associated proteins for active transcription. In cancer, however, $\mathrm{CpG}$ islands in promoter regions become hypermethylated, and this event is believed to cause inappropriate transcriptional silencing of numerous tumor suppressors and other genes with important functions in 
carcinogenesis (Fig. 1) [16]. The recruitment of transcriptional proteins to DNA is reduced by hypermethylated $\mathrm{CpG}$ islands, thus resulting in gene silencing [17]. Alternatively, methylated $\mathrm{CpG}$ islands provide binding sites for various methyl-binding proteins (MBDs), such as MBD1-MBD4 and methyl CpG binding protein 2 (MeCP2), which can mediate gene repression by interacting with HDACs [18]. Surprisingly, promoter $\mathrm{CpG}$ island hypermethylation-mediated gene silencing is at least as common as mutational alterations in the classic tumor-suppressor genes in human cancer [19]. The list of cancer-related genes that are inactivated by $\mathrm{CpG}$ hypermethylation is ever growing with advances in techniques. Examples of these genes include human mutL homolog 1 (hMLH1), $\mathrm{O}^{6}$ alkylguanine DNA alkyltransferase (MGMT) [20, 21], $\mathrm{p} 16^{\mathrm{INK} 4 \mathrm{a}}, \mathrm{p} 15^{\mathrm{INK} 4 \mathrm{~b}}[22,23]$, B cell lymphoma (Bcl-2), and death-associated protein kinase 1 (DAPK) [24, 25]. The studies conducted in our group demonstrated that nuclear factor (erythroid-derived 2)-like 2 ( $\mathrm{Nrf} 2$ ) expression is down- regulated in TRAMP $\mathrm{C} 1$ cells and JB6 $\mathrm{P}+$ cells due to promoter hypermethylation, and the expression of these genes can be restored by reducing the promoter methylation status with various phytochemical treatments [26-29, 30•]. This effect will be further reviewed in "Dietary Phytochemicals Modulate Epigenetic Modifications." Other than the hypermethylation of promoter $\mathrm{CpG}$ islands, global DNA hypomethylation in tumor cells compared with normal cells has been reported repeatedly (Fig. 1) [31, 32]. Genome-wide hypomethylation is suggested to be associated with enhanced genomic instability and can thereby facilitate tumor progression [33]. Thus, an imbalance of DNA methylation between genomewide hypomethylation and regional hypermethylation may characterize human neoplasia [34].

The precise DNA methylation patterns in the mammalian genome are known to be regulated by DNMTs (Fig. 1). DNMT3a and DNMT3b act cooperatively to establish de novo methylation independent of replication, whereas

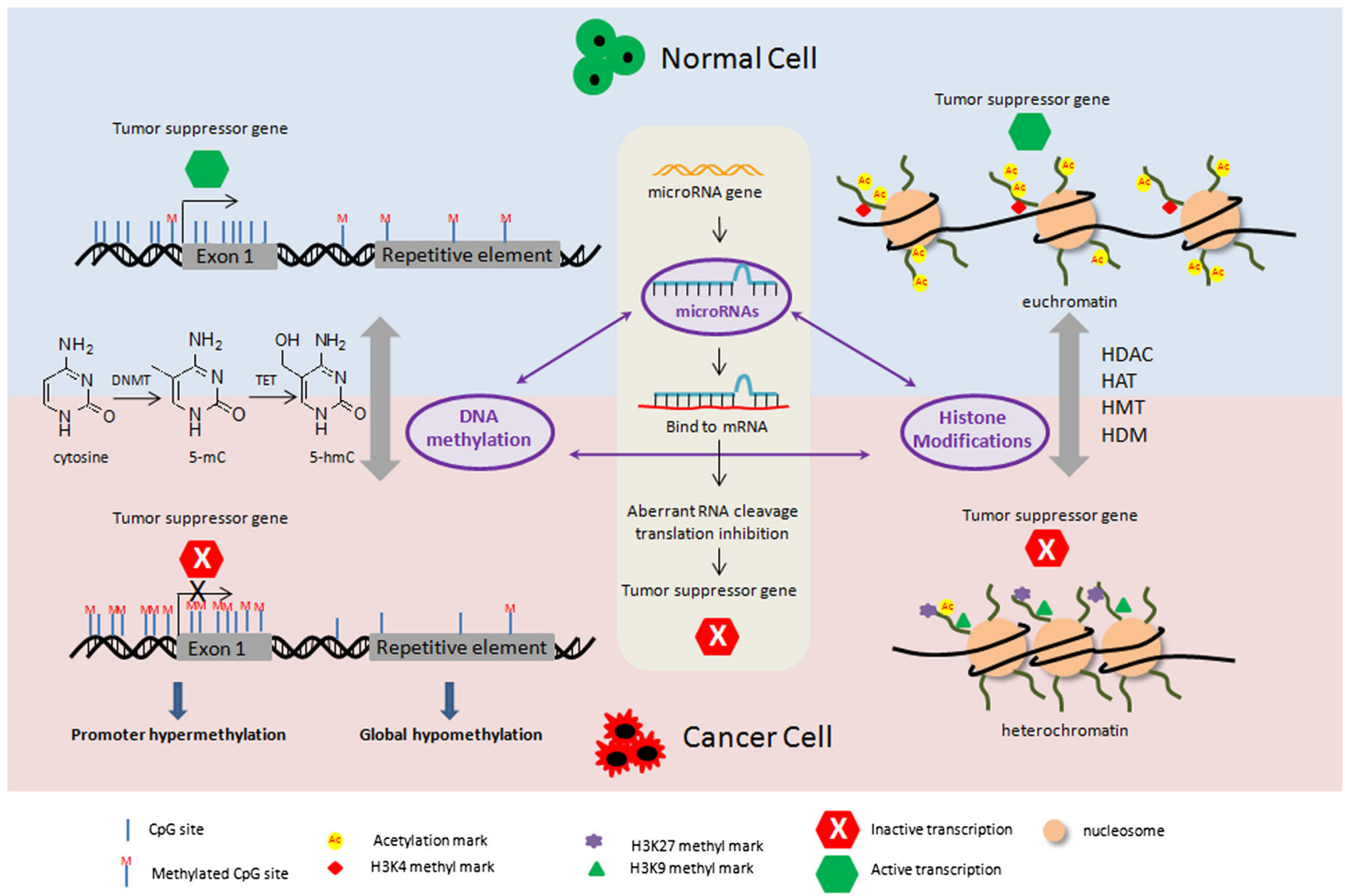

Fig. 1 Schematic representation showing epigenetic modifications of tumor suppressor genes in normal and in cancer cell. $\mathrm{CpG}$ island of promoter region remains hypomethylated to facilitate active transcription of tumor suppressor genes in normal cells. In cancer cells, however, promoter hypermethylation of tumor suppressor genes is frequently detected. In addition, genome-wide hypomethylation in cancer cells has been reported. The enzymes such as DNMT and TET dynamically regulate the DNA methylation. Acetylation and methylation on the histone tails influence the chromatin structure. For example, lysine acetylation and $\mathrm{H} 3 \mathrm{~K} 4$ methylation are associated with active transcription in euchromatin in normal cells. In cancer cells, loss of lysine acetylation and methylation at $\mathrm{H} 3 \mathrm{~K} 9$ and $\mathrm{H} 3 \mathrm{~K} 27$ leads to the repression of some tumor suppressor genes. The enzymes such as HDAC, HAT, HDM, and HMT catalyze histone acetylation and methylation. miRNAs bind and interfere with mRNAs and specifically target mRNA degradation or translation inhibition of tumor suppressor genes in cancer cells. The interplay of epigenetic pathways is shown at the center of the figure 
DNMT1 maintains methylation patterns during DNA replication by preferentially methylating hemimethylated DNA [35]. A fourth member, DNMT-3L, was first isolated in 2000 and had been shown to facilitate DNA methylation by interacting with DNMT3a and 3b $[36,37]$. Given that the DNMT enzymes are modestly overexpressed in many types of tumor cells and that the inhibition of DNMTs has been found to reduce tumor formation in various mouse models [38, 39], the search for and studies of DNMT inhibitors have become extremely popular. Successful examples include FDAapproved anticancer drugs, potent DNMT inhibitors under clinical trials, and numerous dietary chemopreventive phytochemicals that have been identified in preclinical models. Although the enzymes that regulate DNA methylation have been well characterized, those that mediate methyl group removal are still elusive. A novel ten-eleven translocation (TET) enzyme family that is capable of modifying 5-methylcytosine to 5-hydroxymethylcytosine through oxidation has been discovered in recent years (Fig. 1) [40, 41•]. We anticipate many more exciting discoveries regarding the mechanistic roles of TET in the dynamic regulation of DNA methylation to enhance our understanding of DNA methylation in tumorigenesis.

\section{Histone Modification}

The covalent modification of histone proteins also plays a critical role in regulating gene expression, chromatin structure, cellular identity, and, ultimately, carcinogenesis. Histone proteins $(\mathrm{H} 3, \mathrm{H} 4, \mathrm{H} 2 \mathrm{~A}, \mathrm{H} 2 \mathrm{~B}$, and $\mathrm{H} 1)$ are at the heart of chromatin structure and act as scaffolds to wrap $\sim 146 \mathrm{bp}$ of eukaryotic DNA into repeating nucleosomes, which are further folded into compact chromatin fibers $(\sim 30 \mathrm{~nm})$ [42]. The chromatin structure, which is closely involved in gene transcription, replication, and repair, is regulated by the "histone code," known as the language of histone modification [43]. The two distinct chromatin structures, namely, heterochromatin and euchromatin, represent a tightly packed structure with repressed gene transcription or a loosely packed structure with active gene transcription, respectively (Fig. 1) [44]. While highly conserved, specific residues such as lysine, arginine, and serine, on the N-terminal tails of histones can undergo extensive posttranslational modifications, including methylation, acetylation, phosphorylation, ubiquitination, sumoylation, and ADP ribosylation [45].

Histone modifications can lead to either gene activation or repression, depending on which residues are modified and what types of modifications are involved. Usually, lysine acetylation alters nucleosomal conformation by neutralizing the positive charge, thereby increasing the accessibility of transcriptional factors to chromatin and resulting in transcriptional activation (Fig. 1) [46]. Histone acetylation is dynamically catalyzed by enzymes that add [histone acetyltransferases (HATs)] and remove [histone deacetyltransferases (HDACs)] acetyl groups (Fig. 1). To date, 18 HDACs and 25 HATs enzymes have been identified and classified into several families, and these enzymes are capable of controlling various physiological functions [47••]. The loss of acetyl groups in H4-lysine 16 and the overexpression of certain HDACs (1, 2, and 6) have been demonstrated in a number of cancers [48]. Notably, two HDAC inhibitors have already been approved by the FDA, and more novel inhibitors are currently undergoing clinical investigations for the treatment of a broad range of cancers $[8 \cdot]$. It is exciting to note that some dietary phytochemicals may be involved in chromatin remodeling by targeting HDACs and HATs, highlighting their potential in cancer chemoprevention [49•].

Unlike lysine acetylation, methylation at lysine residues appears to activate or repress transcription depending upon which residue is methylated and the degree of the methylation. For example, methylated H3K4, H3K36, and H3K79 are generally associated with active genes in euchromatin, whereas the methylation at $\mathrm{H} 3 \mathrm{~K} 9, \mathrm{H} 3 \mathrm{~K} 27$, and H4K20 leads to gene repression (Fig. 1) [50]. Moreover, histone methylation has been suggested to cooperate with DNA methylation. For example, DNA methylation is associated with H3K9 methylation [51]. Histone methyltransferases (HMTs) and histone demethylases (HDMs) dynamically regulate histone methylation (Fig. 1). In contrast to HATs, HMTs specifically target certain lysine residues; for example, enhancer of zeste homo$\log 2$ (EZH2) is primarily responsible for $\mathrm{H} 3 \mathrm{~K} 27$ methylation [52]. Investigations in recent years have implicated hyperactive EZH2 in the development of prostate and breast cancer via its histone methylation-induced repression of tumor suppressors [53], making this enzyme a promising chemotherapeutic target.

\section{MicroRNAs}

MicroRNAs (miRNAs) are small non-coding RNAs approximately 22 nucleotides in length that are increasingly recognized as important players in epigenetic gene regulation in mammals. By specifically targeting mRNA degradation or translation inhibition, miRNAs can bind and interfere with a wide spectrum of transcripts and profoundly influence cancerrelated processes, such as proliferation, apoptosis, differentiation, cell cycle, and migration (Fig. 1) [54]. Since the deregulation of miRNA in cancer was first documented in 2002 [55], the network of miRNAs identified in the cancer-related processes, their tissue distributions, and their potential targets have rapidly grown, elucidating their extensive roles in carcinogenesis and chemotherapy. For example, miR-155 and miR-21 have been found to be overexpressed in many cancer types [56, 57], and the attenuated expression of miR-let7 was 
observed in human lung cancers [58]. Interestingly, the expression of miRNAs can be controlled by epigenetic mechanisms, such as DNA methylation and histone modifications. Moreover, miRNAs can target key enzymes, such as DNMTs and EZH2, which mediate epigenetic mechanisms, thereby modulating the epigenetic landscape of cells (Fig. 1) [59]. Progress had been made in utilizing miRNAs in cancer prognosis and therapy. Notably, the first miRNA mimic entered the clinic for the treatment of liver cancer patients in 2013 [60]. In addition, the interaction between dietary phytochemicals and miRNAs has been investigated in cancer cells. Hence, miRNAs might be a promising target for chemopreventive dietary phytochemicals.

\section{Dietary Phytochemicals Modulate Epigenetic Modifications}

Environmental and dietary factors can influence the pathological progression of diseases, including cancer. Some naturally occurring phytochemicals that are common secondary metabolites in fruits and vegetables have been demonstrated to be beneficial for human health through various actions, including ameliorating oxidative stress, inducing detoxification enzymes, inhibiting nitrosamine formation, binding/diluting carcinogens in the digestive tract, altering hormone metabolism, and modulating carcinogenic cellular and signaling events [61]. Recently, accumulating research has demonstrated that dietary phytochemicals can alter the epigenome and may help to prevent and treat human cancer. Here, we review the most recent studies regarding the epigenetic role of dietary phytochemicals, including polyphenols [quercetin, apigenin, (-)epigallocatechin-3-gallate (EGCG), genistein, resveratrol, and curcumin], organosulfur compounds [sulforaphane (SFN), phenethyl isothiocyanate (PEITC), diallyl disulfide (DADS)], and indoles [diindolylmethane (DIM)] in cancer chemoprevention and therapy. We also discussed the latest progress in the identification of chemopreventive phytochemicals from Chinese herbal medicine in modulating epigenetic mechanisms. The epigenetic modifications regulated by phytochemicals are summarized in Table 1.

\section{Polyphenols}

Quercetin, a flavonol with yellow color, is widely found in fruits, vegetables, and grains. Quercetin was shown to inhibit the recombinant prokaryotic SssI DNMT- and human DNMT1-mediated DNA methylation [62]. Quercetin suppresses the growth of the human colon cancer cell line RKO via demethylation of the p16INK4a gene promoter [63]. Quercetin has been found to block the binding of the transactivators cAMP-response element-binding protein 2 (CREB2), c-Jun, CCAAT-enhancer-binding protein beta $(\mathrm{C} / \mathrm{EBP} \beta)$, and nuclear factor kappa B (NF-kB) to the COX-2 promoter. In addition, quercetin suppresses COX-2 expression in breast cancer cells by attenuating p300/HAT-mediated signaling [64]. Moreover, quercetin induces Fas ligand-related apoptosis through the activation of the c-Jun/AP-1 signaling pathway, the induction of HAT, and the inhibition of HADC in HL-60 cells [65]. Quercetin was also found to induce senescence in glioma cells via the inhibition of HDACs [66]. A quercetin-rich diet has been reported to influence miRNA expression in human lung cancer tissues, including the tumor suppressor let-7 family and carcinogenesis-related miR-146, miR-26, and miR-17 [67]. Quercetin also up-regulates miR$142-3 p$, a negative regulator of heat shock protein 70 , which is related to the inhibition of the cell proliferation of pancreatic ductal adenocarcinoma cells (MIA PaCa-2, Capan-1, and S2013) [68].

Apigenin is a yellow flavone compound in fruits and vegetables, especially in parsley, celery, and chamomile tea. In our recent study, we found that apigenin effectively demethylated the Nrf2 promoter, resulting in an increase in the mRNA and protein expression of Nrf2 and the Nrf2 downstream target gene $\mathrm{NAD}[\mathrm{P}] \mathrm{H}$ :quinine oxidoreductase-1 (NQO1) in skin epidermal JB6 P+ cells. This effect was associated with the reduced expression of epigenetic proteins, including DNMT1, DNMT3a, DNMT3b, and some HDACs [69]. Apigenin also induces growth arrest and apoptosis in human prostate cancer cells through the up-regulation of global histone $\mathrm{H} 3$ and $\mathrm{H} 4$ acetylation and hyperacetylation of histone $\mathrm{H} 3$ on the $\mathrm{p} 21 /$ wafl promoter in prostate cancer PC-3 and 22Rv1 cells. These effects may be caused by the inhibitive effect of apigenin on HDAC enzyme activity and the expression of HDAC1 and HDAC3 [70]. The tumor suppressor miR-138 is correlated with telomerase activity in many human cancers, and apigenin-induced overexpression of miR-138 has been demonstrated to powerfully induce apoptosis of human malignant neuroblastoma in cell culture and animal models [71].

(-)-Epigallocatechin-3-gallate (EGCG) is one of the most abundant catechins in tea leaves and has been identified as a non-nucleoside DNMT inhibitor. The restoration of Wnt inhibitory factor 1 (WIF-1) expression by EGCG treatment, occurring via the demethylation of the WIF-1 promoter, has been found in lung cancer $\mathrm{H} 460$ and A549 cell lines [72]. A recent study reported that EGCG treatment inhibits DNMT transcript levels and the protein expression of DNMT1, HDAC1, and $\mathrm{MeCP} 2$, effectively reactivating genes silenced by promoter methylation, such as estrogen receptor $\alpha(E R \alpha)$, progesterone receptor $\mathrm{B}$ (PRB), target of methylation-induced silencing-1 (TMS1), Cyclin D2 (G1/S-specific cyclin-D2), and MGMT in MCF-7 cells [73]. EGCG treatment was found to reactivate the tumor suppressor gene $\mathrm{p} 16 \mathrm{INK} 4 \mathrm{a}$ and $\mathrm{Cip} 1 / \mathrm{p} 21$ by reducing DNA methylation and increasing histone acetylation in human epidermoid carcinoma A431 cells [74]. EGCG may 
Table 1 Epigenetic modifications by phytochemicals

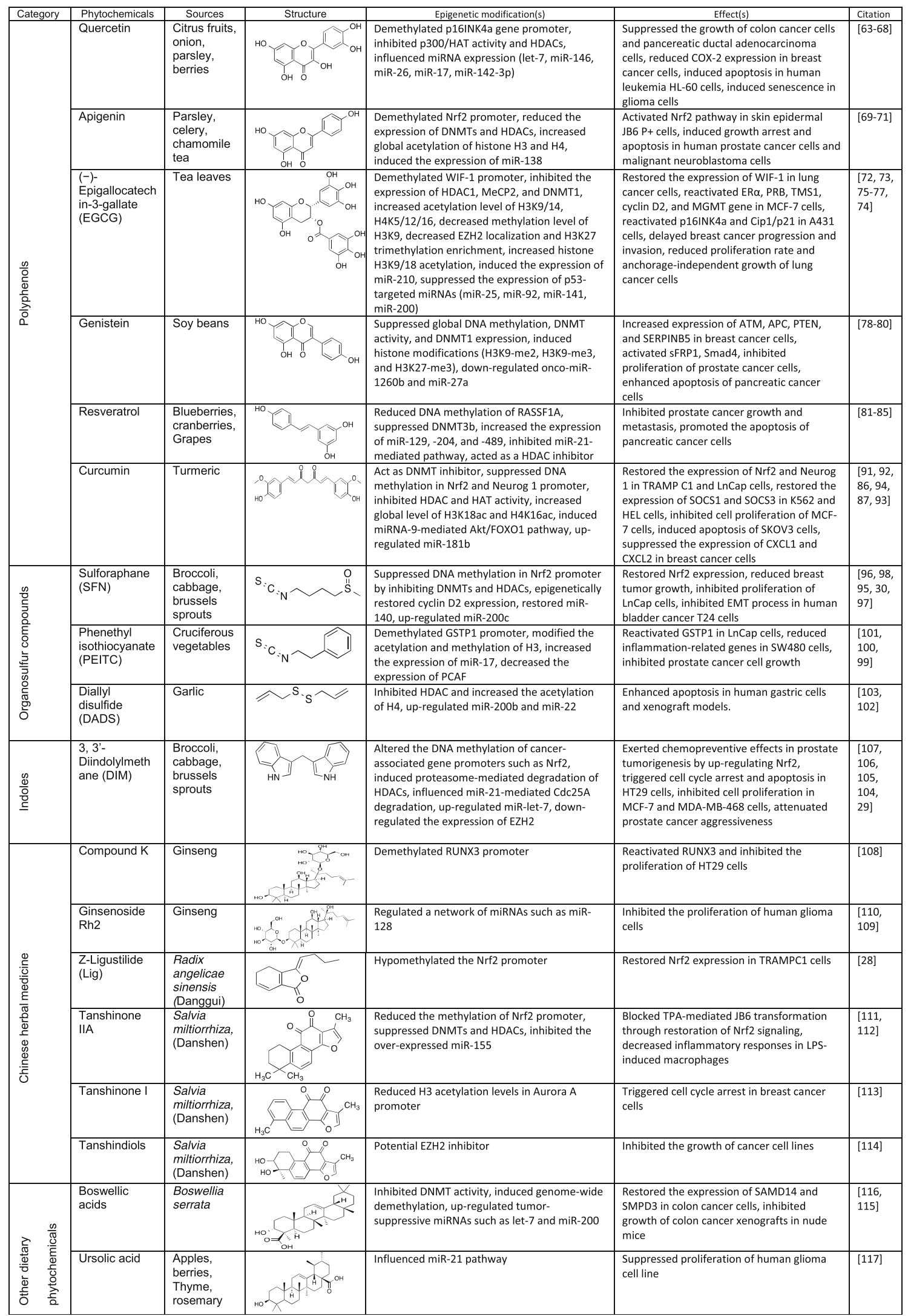


delay breast cancer progression and invasion via the induction of matrix metalloproteinase-3 (TIMP-3) expression. The proposed mechanism for this effect is that EGCG decreases EZH2 localization and $\mathrm{H} 3 \mathrm{~K} 27$ trimethylation enrichment at the TIMP-3 promoter, with a concomitant increase in histone H3K9/18 acetylation, in breast cancer cells [75]. EGCG also induces the expression of miR-210, a major miRNA regulated by hypoxia-induced factor (HIF)-1 $\alpha$, in lung cancer cells, resulting in a reduced cell proliferation rate and anchorageindependent growth [76]. EGCG can suppress the expression of p53-targeting miRNAs, including miR-25, miR-92, miR141, and miR-200a, which are induced by the environmental carcinogen benzo[a]pyrene $(\mathrm{BaP})$ in multiple myeloma, a common and deadly cancer of blood plasma cells [77].

Genistein, an isoflavone, is a major phytoestrogen compound in soy beans (Glycine max). Genistein has been demonstrated to suppress global DNA methylation, DNMT activity, and DNMT1 expression. These effects lead to promoter hypomethylation and increased mRNA expression of multiple tumor suppressor genes, including ataxia telangiectasia mutated (ATM), adenomatous polyposis coli (APC), phosphatase and tensin homolog (PTEN), and mammary serpin peptidase inhibitor (SERPINB5), in human breast cancer MCF-7 and MDA-MB-231 cells [78]. Genistein induces the expression of two tumor suppressor genes, secreted frizzled-related protein 1 (sFRP1), and Smad4 (mothers against decapentaplegic homolog 4), via the demethylation of their promoter regions and histone modifications, such as H3K9-me2, H3K9-me3, and H3K27-me3, in prostate cancer cells [79]. Genistein also down-regulates onco-miRNA-1260b in prostate cancer cells, resulting in the up-regulation of sFRP1 and Smad4 and the inhibition of cell proliferation and invasion [79]. miR-27a down-regulation by genistein leads to enhanced apoptosis and reduced cell growth and invasion in pancreatic cancer cells [80].

Resveratrol is a stilbenoid, a type of natural polyphenol, and is found in blueberries, cranberries, and grapes. DNA methylation of the tumor suppressor gene RASSF1A (Ras association domain-containing protein 1) was reported to be reduced by resveratrol intake (twice daily for 12 weeks) in the breasts of women at high breast cancer risk [81]. Resveratrol suppressed the increase in DNMT3b expression in estradiolinduced mammary tumor tissue in female ACI rats, an effect that may increase the expression of miRNA-129, miRNA204, and miRNA-489 [82]. The role of resveratrol as a HDAC inhibitor has also been demonstrated in glioma cells and human-derived hepatoblastoma cells [83]. Recent studies suggested that resveratrol inhibits prostate cancer growth and metastasis and promotes the apoptosis of pancreatic cancer cells by inhibiting a miRNA-21-mediated pathway [84, 85].

Curcumin, a curcuminoid, is the primary component in the most popular Indian spice, turmeric (Curcuma longa). Growing evidence shows that curcumin harbors DNA demethylation potential in various cancer cell lines and might be a DNMT inhibitor [86-89]. For example, studies conducted in our laboratory suggested that curcumin restored the expression of Nrf2 and Neurogenin-1 (Neurog1) in murine prostate cancer Tramp C1 cells and human prostate cancer LnCap cells, respectively, by suppressing DNA methylation in the promoter region $[86,87]$. The hypomethylation effect of some novel synthetic curcumin analogs, such as EF31 and UBS109, has also been described to activate silenced genes, including p16, secreted protein acidic and rich in cysteine (SPARC), and epithelial cadherin (E-cadherin), in pancreatic cancer MiaPaCa-2 and PANC-1 cells [90]. Curcumin has also been reported to modulate the activities of HDAC and HAT. Curcumin restored the expression of SOCS1 and SOCS3, suppressors of cytokine signaling, via the inhibition of HDAC activity (especially HDAC8), resulting in increased histone acetylation in the SOCS1 and SOCS3 promoter regions of the myeloproliferative neoplasm cell lines K562 and HEL [91]. In breast tumor MCF-7 cells, the inhibitory effects of curcumin in the activities of HAT have also been demonstrated, with increased global levels of acetylated H3K18 and H4K16, potentially leading to the arrest of cell proliferation [92]. Curcumin may also induce apoptosis of ovarian cancer SKOV3 cells through inducing the miRNA-9-mediated Akt/ forkhead box protein O1 (FOXO1) pathway [93]. The upregulation of miRNA-181b by curcumin was found to suppress the expression of the pro-inflammatory cytokines chemokine ( $\mathrm{C}-\mathrm{X}-\mathrm{C}$ motif) ligand 1 (CXCL1) and CXCL2, leading to the diminished proliferation and invasion of breast cancer cells [94].

\section{Organosulfur Compounds}

Sulforaphane (SFN) is a bioactive isothiocyanate, a group of organosulfur compounds, which are abundant in cruciferous vegetables, such as broccoli, cabbage, and brussels sprouts. According to our recent studies, SFN suppresses DNA methylation of the Nrf2 promoter in mouse skin JB6 and prostate Tramp C1 cells by down-regulating DNMTs and HDACs. These effects may contribute to its preventive potentials against TPA-induced skin transformation and prostate carcinogenesis, respectively $[95 \bullet, 30 \bullet$. SFN has also been demonstrated to exhibit antiproliferative effects on $\mathrm{LnCaP}$ prostate cancer cells by epigenetically restoring the expression of cyclin D2 [96]. The restoration of miR-140 by SFN, accompanied by the reduced expression of SOX9 and aldehyde dehydrogenases 1 (ALDH1), has been reported to result in decreased breast tumor growth in vivo [97]. SFN also inhibits the epithelial-to-mesenchymal transition (EMT) process in human bladder cancer T24 cells, and the up-regulation of miRNA-200c by SFN may be one of the mechanisms underlying this effect [98]. 
Phenethyl isothiocyanate (PEITC), another isothiocyanate, exists in some cruciferous vegetables. PEITC has been reported to be able to demethylate and reactivate pi-class glutathione S-transferase (GSTP1). This protein is a frequently silenced detoxifying enzyme that is highly associated with prostate carcinogenesis through its regulation of the cross-talk between DNA and chromatin in LNCaP cells [99]. PEITC was also observed to modify the acetylation and methylation of histone 3 in human colon cancer SW480 cells, leading to the downregulation of some inflammation-related genes, such as chemokine ligand 2 (CCL2), CD40, $\mathrm{C}-\mathrm{X}-\mathrm{C}$ motif chemokine 10 (CXCL10), colony stimulating factor 2 (CSF2), interleukin 8 (IL-8), NF- $\mathrm{kB}$, and tumor necrosis factor, alpha-induced protein 3 (TNFaip3) [100]. PEITC treatment significantly increased the expression of miRNA-17 and decreased the expression of p300/CBP-associated factor (PCAF) in dihydrotestosterone-stimulated $\mathrm{LNCaP}$ cells, which might contribute to the inhibitory effect of PEITC against androgen receptor (AR) transcriptional activity and cell growth in prostate cancer [101]

Diallyl disulfide (DADS) is one of the principal sulfur compounds in Allium vegetables, such as garlic (Allium sativum). DADS has been found to exhibit an inhibitory effect on HDAC, resulting in hyperacetylation of histone 4 in the breast cancer MCF-7 cell line [102]. In addition, DADS treatment has been demonstrated to impair proliferation and enhance apoptosis in both human gastric cell lines and xenograft models. This effect occurred through the Wnt-1 signaling pathway and was mediated by the up-regulation of miRNA200b and miRNA-22 [103].

\section{Indoles}

3,3'-Diindolylmethane (DIM), an indole compound, is derived from glucosinolate indole-3-carbinol (I3C) in cruciferous vegetables, including broccoli, cabbage, cauliflower, and brussels sprouts. In addition to SFN, DIM can alter the DNA methylation status of many cancer-associated gene promoters in normal PrECs as well as in the prostate cancer cell lines LnCap and PC3 [104]. Similarly, DIM exerts its chemopreventive effects in prostate tumorigenesis by epigenetically demethylating the Nrf2 promoter and up-regulating the expression of Nrf2 and its downstream gene NQO1 [29]. The proteasome-mediated degradation of class I HDACs (HDAC1, HDAC2, HDAC3, and HDAC8) induced by DIM triggers cell cycle arrest and apoptosis in human colon cancer HT-29 cells and in tumor xenografts [105]. DIM also inhibits cell proliferation in human breast cancer MCF-7 (estrogendependent) and MDA-MB-468 (estrogen receptor-negative, p53 mutant) cells via miRNA-21-mediated Cdc25A (cell division cycle 25 homolog A) degradation [106]. A phase II clinical study in patients prior to radical prostatectomy suggested that formulated DIM intervention could attenuate prostate cancer aggressiveness via the up-regulation of miRNA let-7 and down-regulation of EZH2 expression in tissue specimens [107].

Phytochemicals from Traditional Chinese Herbal Medicine

During the last few decades, great progress had been made in the identification of chemopreventive agents and anticancer drugs in traditional Chinese herbal medicine. Recently, the potential of the components from Chinese herbs to influence epigenetic mechanisms in cancer prevention have been recognized. Ginseng is one of the most commonly used herbs in East Asia. Compound K [20-O- $\beta$-(D-glucopyranosyl)-20(S)protopanaxadiol], the main metabolite of ginseng saponin, was found to inhibit the proliferation of human HT29 human colon cancer cells by demethylating and reactivating runtrelated transcription factor 3 (RUNX 3), which is associated with reduced DNMT1 activity [108]. Ginsenoside Rh2 is another biologically active triterpene saponin extracted from ginseng. The chemopreventive effect of $\mathrm{Rh} 2$ in inhibiting the proliferation of human glioma cells had been demonstrated to involve epigenetic modifications, such as the regulation of miRNAs. Specifically, the up-regulation of miR-128 by the treatment with $\mathrm{Rh} 2$ had been shown to trigger apoptosisrelated signaling [109]. Similarly, using miRNA microarray analysis, An et al. [110] identified a network of miRNAs regulated by treatment with $\mathrm{Rh} 2$ in nonsmall cell lung cancer A549 cells, which may contribute to the antiproliferative effect of Rh2. A research study from our group demonstrated that the Chinese herb Radix angelicae sinensis (RAS; Danggui) and its bioactive component Z-Ligustilide (Lig) are able to hypomethylate the Nrf2 promoter, resulting in the restoration of Nrf2 and downstream targets such as NQO1, heme oxygenase 1 (HO-1), and UDP-glucuronosyltransferase 1 family, polypeptide A1 (UGT1A1) in murine prostate cancer TRAMP C1 cells [28]. Another Chinese herb with great promise in altering epigenetic mechanisms is Salvia miltiorrhiza, also known as Danshen. We found that tanshinone IIA, one of the main active components from Danshen, blocks TPA (12-Otetradecanoylphorbol-13-acetate)-mediated JB6 transformation through epigenetic regulation of the Nrf2 signaling pathway [111]. Treatment with tanshinone IIA reduced the methylation of the Nrf2 promoter, elevated the expression of Nrf2 and downstream targets, suppressed the protein levels of DNMT1, DNMT3a, DNMT3b, and HDAC3, and inhibited HDAC activity [111]. Another study showed that tanshinone IIA decreases inflammatory responses in LPS-induced macrophages and inhibits the proliferation of inflammation-stimulated colon cancer cells by inhibiting the overexpressed miR-155 in macrophages [112]. Tanshinone I, another main component derived from Danshen, has been shown to trigger cell cycle arrest in several breast cancer cells by down-regulating Aurora A gene expression via the reduction of $\mathrm{H} 3$ acetylation levels in the 
Aurora A promoter [113]. In addition to tanshinones, the primary components, minor components, including tanshindiols, are currently under investigation for their potential antitumor ability by targeting epigenetic modifications. Using molecular docking and an enzyme kinetics approach, Woo et al. [114] proposed that tanshindiols $\mathrm{B}$ and $\mathrm{C}$ are potential EZH2 inhibitors, resulting in the inhibition of the growth of several cancer cell lines.

\section{Other Dietary Phytochemicals}

In addition to above-mentioned dietary phytochemicals, various other natural compounds are currently under investigation regarding their cancer chemopreventive potential through epigenetic modifications. Boswellic acids, a pentacyclic terpenoid derived from the plant Boswellia serrata, have long been used as anti-inflammatory and cancer chemopreventive agents. Recently, Shen et al. demonstrated that boswellic acids inhibit DNMT activity and induce genome-wide demethylation, permitting the restoration of tumor suppressor genes, such as sterile $\alpha$ motif domain containing 14 (SAMD14) and sphingomyelin phosphodiesterase 3 (SMPD3) in colorectal cancer cells [115]. In addition to modulating DNA methylation, boswellic acids were found to significantly upregulate tumor-suppressive miRNAs, such as let-7 and miR200 , and to modulate the expression of downstream targets in several colon cancer cells and tumor xenografts in nude mice [116]. Experimental evidence demonstrated that ursolic acid, another naturally occurring pentacyclic triterpene, suppresses proliferation and induces apoptosis in the human glioma cell line U251 by mediating the miR-21 pathway [117]. A recent study proposed that the antitumor activity of rosemary extracts with high contents of phenolic diterpene carnosic acid and carnosol might involve the up-regulation of glycosyltransferase 3 (GCNT3) and down-regulation of miR-15b in colon and pancreatic cancer cells [118].

\section{Conclusions and Perspectives}

Great accomplishments have been made in recent years in advancing our understanding of epigenetic alterations in the development of cancer. These epigenetic abnormalities are now believed to exist in all cancer types and drive tumor progression along with genetic defects. The reversible and dynamic nature of epigenetic modifications strongly encouraged clinicians and pharmaceutical industries to develop epigenetic biomarkers and therapeutic targets in cancer diagnosis and treatment. However, the complexity of epigenetic pathways, including the interplay of the different epigenetic mechanisms in regulating gene transcription and the genetic mutations in epigenetic regulators, need to be addressed before we can fully apply our current understanding to the clinical field.
For example, histone modification enzymes such as HDACs might be abnormally regulated by genetic or DNA methylation changes in cancer cells. Thus, further systematic studies may facilitate the development of epigenetic research in preventing and treating cancer.

The approval of several DNMT and HDAC inhibitors for clinical use has opened up a new avenue in cancer therapy. However, it could be reasonably argued that epigenetic interventions may be more effective in hematopoietic malignancies than solid malignancies. Factors such as the microenvironment, epigenetic landscape, drug exposure, and drug metabolism appear to be largely different in solid tumors than in hematopoietic malignances. However, more intensive studies regarding these cellular or epigenetic differences are urgently needed to successfully apply the concept of epigenetic therapy across a broader spectrum. Furthermore, adverse effects and a lack of selectivity have hindered the road towards effective epigenetic therapies. Investigations should be conducted regarding whether a selective subset or large numbers of genes will be influenced by the drugs or phytochemicals that target epigenetic modifications. Additionally, based on the crosstalk between genetic and epigenetic mechanisms, combining conventional antitumor drugs with epigenetic therapies or dietary phytochemicals that target epigenetic mechanisms might be a promising strategy for reducing toxicity and resistance.

Accumulating evidence indicates that some dietary phytochemicals can modulate epigenetic mechanisms. Here, we summarized and discussed the latest findings in the past 3 years. Together with numerous reports published more than 3 years ago, it is now clear that these natural compounds hold great promise in cancer prevention via acting on a variety of epigenetic targets. However, we should also notice that the success of epigenetic interventions elicited by phytochemicals was mostly limited in preclinical models. Thus, future studies should be carefully designed on the translation of these natural agents' effects to prevent human malignancies in clinical settings. Moreover, most phytochemicals have been reported to influence a wide range of epigenetic regulators. Therefore, understanding the global patterns of epigenetic modifications that are induced by phytochemicals will help to optimize strategies to prevent and treat cancer.

In summary, aberrant epigenetic modifications, such as DNA methylation, histone modifications, and miRNA, add another layer of complexity to the development of human cancer. The identification of dietary phytochemicals that modulate epigenetic modifications offers promising benefits in the management of human cancer.

Acknowledgments This work was supported in part by institutional funds and by R01-CA118947 and R01-CA152826, from the National Cancer Institute (NCI), R01AT007065 from the National Center for 
Complementary and Alternative Medicines (NCCAM), and the Office of Dietary Supplements (ODS). We thank all the members in the laboratory for the discussion and preparation of this review.

\section{Compliance with Ethics Guidelines}

Conflict of Interest Yue Guo, Zheng-Yuan Su, and Ah-Ng Tony Kong declare that they have no conflict of interest.

Human and Animal Rights and Informed Consent This article does not contain any studies with human or animal subjects performed by any of the authors.

\section{References}

Papers of particular interest, published recently, have been highlighted as:

- Of importance

•- Of major importance

1. Hanahan D, Weinberg RA. The hallmarks of cancer. Cell. 2000;100(1):57-70.

2. Sharma S, Kelly TK, Jones PA. Epigenetics in cancer. Carcinogenesis. 2010;31(1):27-36. doi:10.1093/carcin/bgp220.

3. Waddington $\mathrm{CH}$. The epigenotype. 1942. Int J Epidemiol. 2012;41(1):10-3. doi:10.1093/ije/dyr184.

4. Wolffe AP, Matzke MA. Epigenetics: regulation through repression. Science. 1999;286(5439):481-6.

5. Feinberg AP, Tycko B. The history of cancer epigenetics. Nat Rev Cancer. 2004;4(2):143-53. doi:10.1038/nrc1279.

6. Sandoval J, Esteller M. Cancer epigenomics: beyond genomics. Curr Opin Genet Dev. 2012;22(1):50-5. doi:10.1016/j.gde.2012. 02.008 .

7.• You JS, Jones PA. Cancer genetics and epigenetics: two sides of the same coin? Cancer Cell. 2012;22(1):9-20. doi:10.1016/j.ccr. 2012.06.008. An important overview of the crosstalk between epigenetics and genetics in cancer.

8. Dhanak D, Jackson P. Development and classes of epigenetic drugs for cancer. Biochem Biophys Res Commun. 2014. doi:10. 1016/j.bbrc.2014.07.006. A updated summary of the recent progress in the discovery and development of epigenetic therapeutics in the treatment of cancer.

9. Kantarjian HM, Giles FJ, Greenberg PL, Paquette RL, Wang ES, Gabrilove JL, et al. Phase 2 study of romiplostim in patients with low- or intermediate-risk myelodysplastic syndrome receiving azacitidine therapy. Blood. 2010;116(17):3163-70. doi:10.1182/ blood-2010-03-274753.

10. Dolinoy DC, Weidman JR, Jirtle RL. Epigenetic gene regulation: linking early developmental environment to adult disease. Reprod Toxicol. 2007;23(3):297-307. doi:10.1016/j.reprotox.2006.08. 012 .

11. Lee KW, Bode AM, Dong Z. Molecular targets of phytochemicals for cancer prevention. Nat Rev Cancer. 2011;11(3):211-8. doi:10. 1038/nrc3017.

12. Surh YJ. Cancer chemoprevention with dietary phytochemicals. Nat Rev Cancer. 2003;3(10):768-80. doi:10.1038/nrc1189.

13. Bird A. DNA methylation patterns and epigenetic memory. Genes Dev. 2002;16(1):6-21. doi:10.1101/gad.947102.

14. Wang Y, Leung FC. An evaluation of new criteria for $\mathrm{CpG}$ islands in the human genome as gene markers. Bioinformatics. 2004;20(7):1170-7. doi:10.1093/bioinformatics/bth059.
15. Suzuki MM, Bird A. DNA methylation landscapes: provocative insights from epigenomics. Nat Rev Genet. 2008;9(6):465-76. doi:10.1038/nrg2341.

16. Baylin SB, Herman JG. DNA hypermethylation in tumorigenesis: epigenetics joins genetics. Trends Genet : TIG. 2000;16(4):168 74.

17. Prendergast GC, Ziff EB. Methylation-sensitive sequence-specific DNA binding by the c-Myc basic region. Science. 1991;251(4990):186-9.

18. Nan X, Ng HH, Johnson CA, Laherty CD, Turner BM, Eisenman $\mathrm{RN}$, et al. Transcriptional repression by the methyl-CpG-binding protein $\mathrm{MeCP} 2$ involves a histone deacetylase complex. Nature. 1998;393(6683):386-9. doi:10.1038/30764.

19. Jones PA, Baylin SB. The fundamental role of epigenetic events in cancer. Nat Rev Genet. 2002;3(6):415-28. doi:10.1038/nrg816.

20. Esteller M, Toyota M, Sanchez-Cespedes M, Capella G, Peinado MA, Watkins DN, et al. Inactivation of the DNA repair gene O6methylguanine-DNA methyltransferase by promoter hypermethylation is associated with $\mathrm{G}$ to A mutations in K-ras in colorectal tumorigenesis. Cancer Res. 2000;60(9):2368-71.

21. Simpkins SB, Bocker T, Swisher EM, Mutch DG, Gersell DJ, Kovatich AJ, et al. MLH1 promoter methylation and gene silencing is the primary cause of microsatellite instability in sporadic endometrial cancers. Hum Mol Genet. 1999;8(4):661-6.

22. Hall GL, Shaw RJ, Field EA, Rogers SN, Sutton DN, Woolgar JA, et al. p16 Promoter methylation is a potential predictor of malignant transformation in oral epithelial dysplasia. Cancer Epidemiol biomark Prev : Publ Am Assoc Cancer Res, Cosponsored Am Soc Prev Oncol. 2008;17(8):2174-9. doi:10.1158/1055-9965.EPI-072867.

23. Wemmert S, Bettscheider M, Alt S, Ketter R, Kammers K, Feiden $\mathrm{W}$, et al. p15 promoter methylation - a novel prognostic marker in glioblastoma patients. Int J Oncol. 2009;34(6):1743-8.

24. Carvalho JR, Filipe L, Costa VL, Ribeiro FR, Martins AT, Teixeira $\mathrm{MR}$, et al. Detailed analysis of expression and promoter methylation status of apoptosis-related genes in prostate cancer. Apoptosis : Int J Program Cell Death. 2010;15(8):956-65. doi:10.1007/ s10495-010-0508-6.

25. Narayan G, Arias-Pulido H, Koul S, Vargas H, Zhang FF, Villella $\mathrm{J}$, et al. Frequent promoter methylation of CDH1, DAPK, RARB, and $\mathrm{HIC} 1$ genes in carcinoma of cervix uteri: its relationship to clinical outcome. Mol Cancer. 2003;2:24.

26. Yu S, Khor TO, Cheung KL, Li W, Wu TY, Huang Y, et al. Nrf2 expression is regulated by epigenetic mechanisms in prostate cancer of TRAMP mice. PLoS One. 2010;5(1):e8579. doi:10.1371/ journal.pone.0008579.

27. Huang Y, Khor TO, Shu L, Saw CL, Wu TY, Suh N, et al. A gamma-tocopherol-rich mixture of tocopherols maintains Nrf2 expression in prostate tumors of TRAMP mice via epigenetic inhibition of CpG methylation. J Nutr. 2012;142(5):818-23. doi:10. 3945/jn.111.153114.

28. Su ZY, Khor TO, Shu L, Lee JH, Saw CL, Wu TY, et al Epigenetic reactivation of $\mathrm{Nrf2}$ in murine prostate cancer TRAMP C1 cells by natural phytochemicals Z-ligustilide and Radix angelica sinensis via promoter $\mathrm{CpG}$ demethylation. Chem Res Toxicol. 2013;26(3):477-85. doi:10.1021/tx300524p.

29. Wu TY, Khor TO, Su ZY, Saw CL, Shu L, Cheung KL, et al. Epigenetic modifications of Nrf2 by 3,3'-diindolylmethane in vitro in TRAMP $\mathrm{C} 1$ cell line and in vivo TRAMP prostate tumors. AAPS J. 2013;15(3):864-74. doi:10.1208/s12248-0139493-3.

30. Zhang C, Su ZY, Khor TO, Shu L, Kong AN. Sulforaphane enhances Nrf2 expression in prostate cancer TRAMP C1 cells through epigenetic regulation. Biochem Pharmacol. 2013;85(9): 1398-404. doi:10.1016/j.bcp.2013.02.010. This research article 
proveded Experimental evidence that sulforaphane act as an epigenetic modifier in the regulation of Nrf2 expression.

31. Feinberg AP, Vogelstein B. Hypomethylation distinguishes genes of some human cancers from their normal counterparts. Nature. 1983;301(5895):89-92.

32. Feinberg AP, Gehrke CW, Kuo KC, Ehrlich M. Reduced genomic 5 -methylcytosine content in human colonic neoplasia. Cancer Res. 1988;48(5):1159-61.

33. Rodriguez J, Frigola J, Vendrell E, Risques RA, Fraga MF, Morales $\mathrm{C}$, et al. Chromosomal instability correlates with genome-wide DNA demethylation in human primary colorectal cancers. Cancer Res. 2006;66(17):8462-9468. doi:10.1158/00085472.CAN-06-0293.

34. Baylin SB, Makos M, Wu JJ, Yen RW, de Bustros A, Vertino P, et al. Abnormal patterns of DNA methylation in human neoplasia: potential consequences for tumor progression. Cancer Cells. 1991;3(10):383-90.

35. Kim GD, Ni J, Kelesoglu N, Roberts RJ, Pradhan S. Co-operation and communication between the human maintenance and de novo DNA (cytosine-5) methyltransferases. EMBO J. 2002;21(15): 4183-95.

36. Suetake I, Shinozaki F, Miyagawa J, Takeshima H, Tajima S. DNMT3L stimulates the DNA methylation activity of Dnmt3a and Dnmt3b through a direct interaction. J Biol Chem. 2004;279(26):27816-23. doi:10.1074/jbc.M400181200.

37. Aapola U, Kawasaki K, Scott HS, Ollila J, Vihinen M, Heino M, et al. Isolation and initial characterization of a novel zinc finger gene, DNMT3L, on 21q22.3, related to the cytosine-5methyltransferase 3 gene family. Genomics. 2000;65(3):293-8. doi:10.1006/geno.2000.6168.

38. Robertson KD, Uzvolgyi E, Liang G, Talmadge C, Sumegi J, Gonzales FA, et al. The human DNA methyltransferases (DNMTs) 1, 3a and 3b: coordinate mRNA expression in normal tissues and overexpression in tumors. Nucleic Acids Res. 1999;27(11):2291-8.

39. Subramaniam D, Thombre R, Dhar A, Anant S. DNA methyltransferases: a novel target for prevention and therapy. Front Oncol. 2014;4:80. doi:10.3389/fonc.2014.00080.

40. Tahiliani M, Koh KP, Shen Y, Pastor WA, Bandukwala H, Brudno $Y$, et al. Conversion of 5-methylcytosine to 5hydroxymethylcytosine in mammalian DNA by MLL partner TET1. Science. 2009;324(5929):930-5. doi:10.1126/science. 1170116.

41. Kohli RM, Zhang Y. TET enzymes, TDG and the dynamics of DNA demethylation. Nature. 2013;502(7472):472-9. doi:10. 1038/nature12750. A discussion of the new discoveries and implications of DNA demethylation by TET enzymes.

42. Kornberg RD, Lorch Y. Twenty-five years of the nucleosome, fundamental particle of the eukaryote chromosome. Cell. 1999;98(3):285-94.

43. Strahl BD, Allis CD. The language of covalent histone modifications. Nature. 2000;403(6765):41-5. doi:10.1038/47412.

44. Jenuwein T, Allis CD. Translating the histone code. Science. 2001;293(5532):1074-80. doi:10.1126/science.1063127.

45. Fullgrabe J, Kavanagh E, Joseph B. Histone onco-modifications. Oncogene. 2011;30(31):3391-403. doi:10.1038/onc.2011.121.

46. Struhl K. Histone acetylation and transcriptional regulatory mechanisms. Genes Dev. 1998;12(5):599-606.

47.•• Thakur VS, Deb G, Babcook MA, Gupta S. Plant phytochemicals as epigenetic modulators: role in cancer chemoprevention. AAPS J. 2014;16(1):151-63. doi:10.1208/s12248-013-9548-5. A overview of the role of plant pytochemicals in targeting epigenetic alterations in carcinogenesis.

48. Fraga MF, Ballestar E, Villar-Garea A, Boix-Chornet M, Espada J, Schotta G, et al. Loss of acetylation at Lys16 and trimethylation at
Lys20 of histone $\mathrm{H} 4$ is a common hallmark of human cancer. Nat Genet. 2005;37(4):391-400. doi:10.1038/ng1531.

49. Hardy TM, Tollefsbol TO. Epigenetic diet: impact on the epigenome and cancer. Epigenomics. 2011;3(4):503-18. doi:10.2217/ epi.11.71. A review of the dietary factors that could influence the epigenome in carcinogenesis.

50. Vakoc CR, Sachdeva MM, Wang H, Blobel GA. Profile of histone lysine methylation across transcribed mammalian chromatin. Mol Cell Biol. 2006;26(24):9185-95. doi:10.1128/MCB. 01529-06.

51. Jackson JP, Lindroth AM, Cao X, Jacobsen SE. Control of CpNpG DNA methylation by the KRYPTONITE histone H3 methyltransferase. Nature. 2002;416(6880):556-60. doi:10. 1038/nature731.

52. Dawson MA, Kouzarides T. Cancer epigenetics: from mechanism to therapy. Cell. 2012;150(1):12-27. doi:10.1016/j.cell.2012.06. 013.

53. Kim W, Bird GH, Neff T, Guo G, Kerenyi MA, Walensky LD, et al. Targeted disruption of the EZH2-EED complex inhibits EZH2-dependent cancer. Nat Chem Biol. 2013;9(10):643-50. doi:10.1038/nchembio.1331.

54. Jansson MD, Lund AH. MicroRNA and cancer. Mol Oncol. 2012;6(6):590-610. doi:10.1016/j.molonc.2012.09.006.

55. Calin GA, Dumitru CD, Shimizu M, Bichi R, Zupo S, Noch E et al. Frequent deletions and down-regulation of micro- RNA genes miR15 and miR16 at 13q14 in chronic lymphocytic leukemia. Proc Natl Acad Sci U S A. 2002;99(24):15524-9. doi:10. 1073/pnas.242606799.

56. Faraoni I, Antonetti FR, Cardone J, Bonmassar E. miR-155 gene: a typical multifunctional microRNA. Biochim Biophys Acta. 2009;1792(6):497-505. doi:10.1016/j.bbadis.2009.02.013.

57. Volinia S, Calin GA, Liu CG, Ambs S, Cimmino A, Petrocca F, et al. A microRNA expression signature of human solid tumors defines cancer gene targets. Proc Natl Acad Sci U S A. 2006;103(7):2257-61. doi:10.1073/pnas.0510565103.

58. Takamizawa J, Konishi H, Yanagisawa K, Tomida S, Osada H, Endoh H, et al. Reduced expression of the let-7 microRNAs in human lung cancers in association with shortened postoperative survival. Cancer Res. 2004;64(11):3753-6. doi:10.1158/00085472.CAN-04-0637.

59. Fabbri M, Garzon R, Cimmino A, Liu Z, Zanesi N, Callegari E, et al. MicroRNA-29 family reverts aberrant methylation in lung cancer by targeting DNA methyltransferases $3 \mathrm{~A}$ and 3B. Proc Natl Acad Sci U S A. 2007;104(40):15805-10. doi:10.1073/pnas. 0707628104

60. Bouchie A. First microRNA mimic enters clinic. Nat Biotechnol 2013;31(7):577. doi:10.1038/nbt0713-577.

61. Shukla S, Gupta S. Dietary agents in the chemoprevention of prostate cancer. Nutr Cancer. 2005;53(1):18-32. doi:10.1207/ s15327914nc5301 3.

62. Lee WJ, Shim JY, Z Zhu BT. Mechanisms for the inhibition of DNA methyltransferases by tea catechins and bioflavonoids. Mol Pharmacol. 2005;68(4):1018-30. doi:10.1124/mol.104.008367.

63. Tan S, Wang C, Lu C, Zhao B, Cui Y, Shi X, et al. Quercetin is able to demethylate the p16INK4a gene promoter. Chemotherapy. 2009;55(1):6-10. doi:10.1159/000166383.

64. Xiao X, Shi D, Liu L, Wang J, Xie X, Kang T, et al. Quercetin suppresses cyclooxygenase-2 expression and angiogenesis through inactivation of P300 signaling. PLoS One. 2011;6(8): e22934. doi:10.1371/journal.pone.0022934.

65. Lee WJ, Chen YR, Tseng TH. Quercetin induces FasL-related apoptosis, in part, through promotion of histone $\mathrm{H} 3$ acetylation in human leukemia HL-60 cells. Oncol Rep. 2011;25(2):583-91. doi:10.3892/or.2010.1097.

66. Vargas JE, Filippi-Chiela EC, Suhre T, Kipper FC, Bonatto D, Lenz G. Inhibition of HDAC increases the senescence induced by natural polyphenols in glioma cells. Biochemistry and cell 
biology $=$. Biochim Biol Cell. 2014;92(4):297-304. doi:10.1139/ bcb-2014-0022.

67. Lam TK, Shao S, Zhao Y, Marincola F, Pesatori A, Bertazzi PA, et al. Influence of quercetin-rich food intake on microRNA expression in lung cancer tissues. Cancer Epidemiol biomark Prev : Publ Am Assoc Cancer Res, Cosponsored Am Soc Prev Oncol. 2012;21(12):2176-84. doi:10.1158/1055-9965.EPI-12-0745.

68. MacKenzie TN, Mujumdar N, Banerjee S, Sangwan V, Sarver A, Vickers S, et al. Triptolide induces the expression of miR-142-3p: a negative regulator of heat shock protein 70 and pancreatic cancer cell proliferation. Mol Cancer Ther. 2013;12(7):1266-75. doi:10. 1158/1535-7163.MCT-12-1231.

69. Paredes-Gonzalez X, Fuentes F, Su ZY, Kong AN. Apigenin reactivates $\mathrm{Nrf} 2$ anti-oxidative stress signaling in mouse skin epidermal JB6 P+cells through epigenetics modifications. AAPS J. 2014;16(4):727-35. doi:10.1208/s12248-014-9613-8.

70. Pandey M, Kaur P, Shukla S, Abbas A, Fu P, Gupta S. Plant flavone apigenin inhibits HDAC and remodels chromatin to induce growth arrest and apoptosis in human prostate cancer cells: in vitro and in vivo study. Mol Carcinog. 2012;51(12):952-62. doi:10.1002/mc.20866.

71. Chakrabarti M, Banik NL, Ray SK. miR-138 overexpression is more powerful than hTERT knockdown to potentiate apigenin for apoptosis in neuroblastoma in vitro and in vivo. Exp Cell Res. 2013;319(10):1575-85. doi:10.1016/j.yexcr.2013.02.025.

72. Gao Z, Xu Z, Hung MS, Lin YC, Wang T, Gong M, et al. Promoter demethylation of WIF-1 by epigallocatechin-3-gallate in lung cancer cells. Anticancer Res. 2009;29(6):2025-30.

73. Mirza S, Sharma G, Parshad R, Gupta SD, Pandya P, Ralhan R. Expression of DNA methyltransferases in breast cancer patients and to analyze the effect of natural compounds on DNA methyltransferases and associated proteins. J Breast Cancer. 2013;16(1): 23-31. doi:10.4048/jbc.2013.16.1.23.

74. Nandakumar V, Vaid M, Katiyar SK. (-)-Epigallocatechin-3-gallate reactivates silenced tumor suppressor genes, Cip1/p21 and p16INK4a, by reducing DNA methylation and increasing histones acetylation in human skin cancer cells. Carcinogenesis. 2011;32(4):537-44. doi:10.1093/carcin/bgq285.

75. Deb G, Thakur VS, Limaye AM, Gupta S. Epigenetic induction of tissue inhibitor of matrix metalloproteinase-3 by green tea polyphenols in breast cancer cells. Mol Carcinog. 2014. doi:10.1002/ mc.22121.

76. Wang H, Bian S, Yang CS. Green tea polyphenol EGCG suppresses lung cancer cell growth through upregulating miR-210 expression caused by stabilizing HIF-1alpha. Carcinogenesis. 2011;32(12):1881-9. doi:10.1093/carcin/bgr218.

77. Gordon MW, Yan F, Zhong X, Mazumder PB, Xu-Monette ZY, Zou D, et al. Regulation of p53-targeting microRNAs by polycyclic aromatic hydrocarbons: implications in the etiology of multiple myeloma. Mol Carcinog. 2014. doi:10.1002/mc.22175.

78. Xie Q, Bai Q, Zou LY, Zhang QY, Zhou Y, Chang H, et al. Genistein inhibits DNA methylation and increases expression of tumor suppressor genes in human breast cancer cells. Genes Chromosom Cancer. 2014;53(5):422-31. doi:10.1002/gcc.22154.

79. Hirata H, Hinoda Y, Shahryari V, Deng G, Tanaka Y, Tabatabai ZL, et al. Genistein downregulates onco-miR-1260b and upregulates sFRP1 and Smad4 via demethylation and histone modification in prostate cancer cells. Br J Cancer. 2014;110(6): 1645-54. doi:10.1038/bjc.2014.48.

80. Xia J, Cheng L, Mei C, Ma J, Shi Y, Zeng F, et al. Genistein inhibits cell growth and invasion through regulation of miR-27a in pancreatic cancer cells. Curr Pharm Des. 2014;20(33):5348-53.

81. Zhu W, Qin W, Zhang K, Rottinghaus GE, Chen YC, Kliethermes $\mathrm{B}$, et al. Trans-resveratrol alters mammary promoter hypermethylation in women at increased risk for breast cancer. Nutr Cancer. 2012;64(3):393-400. doi:10.1080/01635581.2012.654926.
82. Qin W, Zhang K, Clarke K, Sauter ER. Methylation and miRNA effects of resveratrol on mammary tumors vs. normal tissue. Nutr Cancer. 2014;66(2):270-7. doi:10.1080/01635581.2014.868910.

83. Venturelli S, Berger A, Bocker A, Busch C, Weiland T, Noor S, et al. Resveratrol as a pan-HDAC inhibitor alters the acetylation status of histone [corrected] proteins in human-derived hepatoblastoma cells. PLoS One. 2013;8(8):e73097. doi:10. 1371/journal.pone.0073097.

84. Liu P, Liang H, Xia Q, Li P, Kong H, Lei P, et al. Resveratrol induces apoptosis of pancreatic cancers cells by inhibiting miR-21 regulation of BCL-2 expression. Clin Transl Oncol : Off Publ Fed Span Oncol Soc Natl Cancer Inst Mexico. 2013;15(9):741-6. doi: 10.1007/s12094-012-0999-4.

85. Sheth S, Jajoo S, Kaur T, Mukherjea D, Sheehan K, Rybak LP, et al. Resveratrol reduces prostate cancer growth and metastasis by inhibiting the Akt/MicroRNA-21 pathway. PLoS One. 2012;7(12):e51655. doi:10.1371/journal.pone.0051655.

86. Khor TO, Huang Y, Wu TY, Shu L, Lee J, Kong AN. Pharmacodynamics of curcumin as DNA hypomethylation agent in restoring the expression of $\mathrm{Nrf} 2$ via promoter CpGs demethylation. Biochem Pharmacol. 2011;82(9):1073-8. doi:10.1016/j. bcp.2011.07.065.

87. Shu L, Khor TO, Lee JH, Boyanapalli SS, Huang Y, Wu TY, et al. Epigenetic $\mathrm{CpG}$ demethylation of the promoter and reactivation of the expression of Neurog 1 by curcumin in prostate $\mathrm{LNCaP}$ cells AAPS J. 2011;13(4):606-14. doi:10.1208/s12248-011-9300-y.

88. Du L, Xie Z, Wu LC, Chiu M, Lin J, Chan KK, et al. Reactivation of RASSF1A in breast cancer cells by curcumin. Nutr Cancer. 2012;64(8):1228-35. doi:10.1080/01635581.2012.717682.

89. Link A, Balaguer F, Shen Y, Lozano JJ, Leung HC, Boland CR, et al. Curcumin modulates DNA methylation in colorectal cancer cells. PLoS One. 2013;8(2):e57709. doi:10.1371/journal.pone. 0057709.

90. Nagaraju GP, Zhu S, Wen J, Farris AB, Adsay VN, Diaz R, et al. Novel synthetic curcumin analogues EF31 and UBS109 are potent DNA hypomethylating agents in pancreatic cancer. Cancer Lett. 2013;341(2):195-203. doi:10.1016/j.canlet.2013.08.002.

91. Chen CQ, Yu K, Yan QX, Xing CY, Chen Y, Yan Z, et al. Pure curcumin increases the expression of SOCS1 and SOCS3 in myeloproliferative neoplasms through suppressing class I histone deacetylases. Carcinogenesis. 2013;34(7):1442-9. doi:10.1093/ carcin/bgt070.

92. Collins HM, Abdelghany MK, Messmer M, Yue B, Deeves SE, Kindle KB, et al. Differential effects of garcinol and curcumin on histone and p53 modifications in tumour cells. BMC Cancer. 2013;13:37. doi:10.1186/1471-2407-13-37.

93. Zhao SF, Zhang X, Zhang XJ, Shi XQ, Yu ZJ, Kan QC. Induction of microRNA-9 mediates cytotoxicity of curcumin against SKOV3 ovarian cancer cells. Asian Pac J Cancer Prev : APJCP. 2014;15(8):3363-8.

94. Kronski E, Fiori ME, Barbieri O, Astigiano S, Mirisola V, Killian $\mathrm{PH}$, et al. miR $181 \mathrm{~b}$ is induced by the chemopreventive polyphenol curcumin and inhibits breast cancer metastasis via downregulation of the inflammatory cytokines CXCL1 and -2 . Mol Oncol. 2014;8(3):581-95. doi:10.1016/j.molonc.2014.01.005.

95. Su ZY, Zhang C, Lee JH, Shu L, Wu TY, Khor TO, et al. Requirement and epigenetics reprogramming of Nrf2 in suppression of tumor promoter TPA-induced mouse skin cell transformation by sulforaphane. Cancer Prev Res. 2014;7(3):319-29. doi:10. 1158/1940-6207.CAPR-13-0313-T. This research article demonstrated that sulforaphane suppressed JB6 cell transforamtion through epigenetic induction of Nrf2.

96. Hsu A, Wong CP, Yu Z, Williams DE, Dashwood RH, Ho E. Promoter de-methylation of cyclin D2 by sulforaphane in prostate cancer cells. Clin Epigenetics. 2011;3:3. doi:10. 1186/1868-7083-3-3. 
97. Li Q, Yao Y, Eades G, Liu Z, Zhang Y, Zhou Q. Downregulation of miR-140 promotes cancer stem cell formation in basal-like early stage breast cancer. Oncogene. 2014;33(20):2589-600. doi: 10.1038/onc.2013.226.

98. Shan Y, Zhang L, Bao Y, Li B, He C, Gao M, et al. Epithelialmesenchymal transition, a novel target of sulforaphane via COX2/MMP2, 9/Snail, ZEB1 and miR-200c/ZEB1 pathways in human bladder cancer cells. J Nutr Biochem. 2013;24(6):1062-9. doi:10. 1016/j.jnutbio.2012.08.004.

99. Wang LG, Beklemisheva A, Liu XM, Ferrari AC, Feng J, Chiao JW. Dual action on promoter demethylation and chromatin by an isothiocyanate restored GSTP1 silenced in prostate cancer. Mol Carcinog. 2007;46(1):24-31. doi:10.1002/mc.20258.

100. Liu Y, Chakravarty S, Dey M. Phenethylisothiocyanate alters siteand promoter-specific histone tail modifications in cancer cells. PLoS One. 2013;8(5):e64535. doi:10.1371/journal.pone. 0064535.

101. Yu C, Gong AY, Chen D, Solelo Leon D, Young CY, Chen XM. Phenethyl isothiocyanate inhibits androgen receptor-regulated transcriptional activity in prostate cancer cells through suppressing PCAF. Mol Nutr Food Res. 2013;57(10):1825-33. doi:10.1002/ mnfr.201200810.

102. Altonsy MO, Habib TN, Andrews SC. Diallyl disulfide-induced apoptosis in a breast-cancer cell line (MCF-7) may be caused by inhibition of histone deacetylation. Nutr Cancer. 2012;64(8): 1251-60. doi:10.1080/01635581.2012.721156.

103. Tang H, Kong Y, Guo J, Tang Y, Xie X, Yang L, et al. Diallyl disulfide suppresses proliferation and induces apoptosis in human gastric cancer through Wnt-1 signaling pathway by up-regulation of miR-200b and miR-22. Cancer Lett. 2013;340(1):72-81. doi: 10.1016/j.canlet.2013.06.027.

104. Wong CP, Hsu A, Buchanan A, Palomera-Sanchez Z, Beaver LM, Houseman EA, et al. Effects of sulforaphane and 3,3'diindolylmethane on genome-wide promoter methylation in normal prostate epithelial cells and prostate cancer cells. PLoS One. 2014;9(1):e86787. doi:10.1371/journal.pone.0086787.

105. Li Y, Li X, Guo B. Chemopreventive agent 3,3'-diindolylmethane selectively induces proteasomal degradation of class I histone deacetylases. Cancer Res. 2010;70(2):646-54. doi:10.1158/ 0008-5472.CAN-09-1924.

106. Jin Y. 3,3'-Diindolylmethane inhibits breast cancer cell growth via miR-21-mediated Cdc25A degradation. Mol Cell Biochem. 2011;358(1-2):345-54. doi:10.1007/s11010-011-0985-0.

107. Kong D, Heath E, Chen W, Cher ML, Powell I, Heilbrun L, et al. Loss of let-7 up-regulates EZH2 in prostate cancer consistent with the acquisition of cancer stem cell signatures that are attenuated by BR-DIM. PLoS One. 2012;7(3):e33729. doi:10.1371/journal. pone.0033729.
108. Kang KA, Kim HS, Kim DH, Hyun JW. The role of a ginseng saponin metabolite as a DNA methyltransferase inhibitor in colorectal cancer cells. Int J Oncol. 2013;43(1):228-36. doi:10.3892/ ijo.2013.1931.

109. Wu N, Wu GC, Hu R, Li M, Feng H. Ginsenoside Rh2 inhibits glioma cell proliferation by targeting microRNA-128. Acta Pharmacol Sin. 2011;32(3):345-53. doi:10.1038/aps.2010.220.

110. An IS, An S, Kwon KJ, Kim YJ, Bae S. Ginsenoside Rh2 mediates changes in the microRNA expression profile of human non-small cell lung cancer A549 cells. Oncol Rep. 2013;29(2):523-8. doi:10. 3892/or.2012.2136.

111. Wang L, Zhang C, Guo Y, Su ZY, Yang Y, Shu L, et al. Blocking of JB6 cell transformation by Tanshinone IIA: epigenetic reactivation of Nrf2 antioxidative stress pathway. AAPS J. 2014;16(6):1214 25. doi:10.1208/s12248-014-9666-8.

112. Tu J, Xing Y, Guo Y, Tang F, Guo L, Xi T. TanshinonelIA ameliorates inflammatory microenvironment of colon cancer cells via repression of microRNA-155. Int Immunopharmacol. 2012;14(4): 353-61. doi:10.1016/j.intimp.2012.08.015.

113. Gong Y, Li Y, Abdolmaleky HM, Li L, Zhou JR. Tanshinones inhibit the growth of breast cancer cells through epigenetic modification of Aurora A expression and function. PLoS One. 2012;7(4):e33656. doi:10.1371/journal.pone.0033656.

114. Woo J, Kim HY, Byun BJ, Chae CH, Lee JY, Ryu SY, et al. Biological evaluation of tanshindiols as EZH2 histone methyltransferase inhibitors. Bioorg Med Chem Lett. 2014;24(11): 2486-92. doi:10.1016/j.bmcl.2014.04.010.

115. Shen Y, Takahashi M, Byun HM, Link A, Sharma N, Balaguer F, et al. Boswellic acid induces epigenetic alterations by modulating DNA methylation in colorectal cancer cells. Cancer Biol Ther. 2012;13(7):542-52. doi:10.4161/cbt.19604.

116. Takahashi M, Sung B, Shen Y, Hur K, Link A, Boland CR, et al. Boswellic acid exerts antitumor effects in colorectal cancer cells by modulating expression of the let-7 and miR-200 microRNA family. Carcinogenesis. 2012;33(12):2441-9. doi:10.1093/carcin/ bgs 286.

117. Wang J, Li Y, Wang X, Jiang C. Ursolic acid inhibits proliferation and induces apoptosis in human glioblastoma cell lines U251 by suppressing TGF-beta1/miR-21/PDCD4 pathway. Basic Clin Pharmacol Toxicol. 2012;111(2):106-12. doi:10.1111/j.17427843.2012.00870.x.

118. Gonzalez-Vallinas M, Molina S, Vicente G, Zarza V, MartinHernandez R, Garcia-Risco MR, et al. Expression of microRNA-15b and the glycosyltransferase GCNT3 correlates with antitumor efficacy of Rosemary diterpenes in colon and pancreatic cancer. PLoS One. 2014;9(6):e98556. doi:10.1371/journal. pone. 0098556 . 